\title{
Rathayibacter gen. nov., Including the Species Rathayibacter rathayi comb. nov., Rathayibacter tritici comb. nov., Rathayibacter iranicus comb. nov., and Six Strains from Annual Grasses
}

\author{
H. I. ZGURSKAYA, L. I. EVTUSHENKO, ${ }^{*}$ V. N. AKIMOV, AND L. V. KALAKOUTSKII \\ All-Russian Collection of Microorganisms, Institute of Biochemistry and Physiology of Microorganisms, \\ Russian Academy of Sciences, Pushchino, Moscow Region, 142292, Russia
}

\begin{abstract}
A new genus, Rathayibacter, is proposed to accommodate three species of gram-positive, aerobic, coryneform bacteria previously placed in the genus Clavibacter (Rathayibacter rathayi comb. nov., Rathayibacter tritici comb. nov., and Rathayibacter iranicus comb. nov.), as well as six strains that were isolated from annual cereal grasses, may be responsible for ryegrass toxicity, and are very similar to the recently described organism Clavibacter toxicus sp. nov. (I. T. Riley and K. M. Ophel, Int. J. Syst. Bacteriol. 42:64-68, 1992). The properties of members of the genus Rathayibacter include coryneform morphology, peptidoglycan based on 2,4-diaminobutyric acid (type B2 $\gamma$ ), predominant menaquinones of the MK-10 type, and phosphatidylglycerol and diphosphatidylglycerol as basic polar lipids. The DNA base compositions range from 63 to $72 \mathrm{~mol} \% \mathrm{G}+\mathrm{C}$. The members of the new genus form a phenetic cluster distinct from Clavibacter spp. at a level of $71 \%$ (simple matching coefficient) and exhibit 7 to $9 \%$ DNA-DNA reassociation with strains of Clavibacter spp. In contrast to Clavibacter spp., most Rathayibacter strains are associated with nematodes belonging to the genus $A$ nguina . The Rathayibacter species differ from species belonging to related genera (e.g., Clavibacter and Agromyces species) in the following characteristics: menaquinone and whole-cell sugar compositions, results of lysozymesodium dodecyl sulfate test (which indicates differences in cell wall composition), ability to utilize a number carbon sources, resistance to bacteriocins of some Clavibacter spp., and other characteristics. The Rathayibacter species can be differentiated from each other by following characteristics: presence or absence of xylose and galactose in the cell walls, fatty acid composition, ability to assimilate various sources of carbon and nitrogen, hydrolytic activity, tolerance to $5 \% \mathrm{NaCl}$ and $0.03 \%$ potassium tellurite, susceptibility to iranicin, and absence or presence of plasmids of certain sizes. The type species of the genus Rathayibacter is $R$. rathayi. The type strains of the species are $R$. rathayi VKM Ac-1601 (= ICMP 2574), R. iranicus VKM Ac-1602 (= ICMP 3496), and $R$. tritici VKM Ac-1603 (= ICMP 2626).
\end{abstract}

Until recently, gram-positive aerobic coryneform bacteria with 2,4-diaminobutyric acid (DAB) in their cell walls were placed in the genus Corynebacterium Lehmann and Neumann $1896(3,7,25,28,41,43,49)$. However, accumulated evidence $(2,3,5,11,15,16,18,27,31,42,46)$ has shown that there is great heterogeneity in this genus as currently circumscribed. Among other things reflecting this heterogeneity is the suggestion (7) that a group of plant-pathogenic Corynebacterium species should be distinguished.

Davis et al. (13) proposed the genus Clavibacter for those coryneform phytopathogenic bacteria that contain $\mathrm{DAB}$ as a marker cell wall component. Accordingly, several species and subspecies were transferred to the genus Clavibacter as Clavibacter iranicus, Clavibacter michiganensis subsp. michiganensis, Clavibacter michiganensis subsp. insidiosus, Clavibacter michiganensis subsp. nebraskensis, Clavibacter michiganensis subsp. sepedonicus, Clavibacter michiganensis subsp. tessellarius, Clavibacter rathayi, and Clavibacter tritici; in addition, a new species with two subspecies, Clavibacter xyli subsp. xyli and Clavibacter xyli subsp. cynodontis, was described. Another new species, Clavibacter toxicus, has been proposed recently by Riley and Ophel (38) for bacteria responsible for annual ryegrass toxicity. The characteristics that differentiate species in the genus

\footnotetext{
${ }^{*}$ Corresponding author.
}

Clavibacter as currently circumscribed include menaquinone type (MK-9 and/or MK-10), composition of cell wall sugars, $\mathrm{G}+\mathrm{C}$ content, pigmentation, and selected physiological features $(13,38)$.

However, at the present time the differences in predominant menaquinone types (together with phylogenetic affinity data and other selected phenotypic characteristics) form the basis for differentiating some coryneform genera $(9,12,44)$. The differences in menaquinone composition, as well as morphological and physiological features, are the basis for distinguishing between the related genera Clavibacter and Agromyces (the members of the genus Agromyces also have a peptidoglycan based on DAB) $(4,54)$. In addition, some genera of coryneform bacteria that are significantly remote phylogenetically may still have no generally acceptable differentiating chemotaxonomic characteristics (10). These organisms can be distinguished phenotypically by fatty acid composition and some cultural and physiological properties.

The chemotaxonomic $(7,11,31)$, physiological (16), and genetic differences (39) among Clavibacter strains, as well as the data mentioned above and the general outlines of development of bacterial systematics $(33,50)$ available, suggest that the members of the genus might be divided into two genera. Preliminary DNA-DNA and DNA-rRNA reassociation data $(15,46)$ do not clearly establish the genus Clavibacter as a homogeneous or heterogeneous genus.

In this paper, we report the results of a comparative 
TABLE 1. Strains investigated

\begin{tabular}{|c|c|c|c|}
\hline Taxon & Strain $^{a}$ & Geographic region & Source $^{b}$ \\
\hline Clavibacter iranicus & ICMP $3496^{\mathrm{T}}$ & Iran & Triticum aestivum \\
\hline \multirow{5}{*}{ Clavibacter rathayi } & ICMP $2574^{\mathrm{T}}$ & New Zealand & Dactylis glomerata \\
\hline & ICMP 2571 & United Kingdom & Dactylis glomerata \\
\hline & ICMP 2572 & New Zealand & Dactylis glomerata \\
\hline & ICMP 2576 & New Zealand & Dactylis glomerata \\
\hline & ICMP 2579 & Scotland & Dactylis glomerata \\
\hline \multirow{6}{*}{ Clavibacter tritici } & ICMP $2626^{\mathrm{T}}$ & Egypt & Triticum aestivum \\
\hline & ICMP 2623 & India & Triticum aestivum \\
\hline & ICMP 2624 & Egypt & Triticum aestivum \\
\hline & ICMP 2625 & India & Triticum aestivum \\
\hline & ICMP 2627 & India & Triticum aestivum \\
\hline & ICMP 2628 & Iran & Triticum aestivum \\
\hline \multirow[t]{6}{*}{ “Corynebacterium sp."” } & ICMP 6306 & Australia & Lolium rigidum \\
\hline & ICMP $6307^{c}$ & Australia & Lolium rigidum \\
\hline & ICMP 6308 & Australia & Phalaris minor \\
\hline & ICMP 6309 & Australia & Phalaris minor \\
\hline & ICMP 6310 & Australia & Phalaris paradoxa \\
\hline & ICMP 6311 & Australia & Avena fatua \\
\hline Clavibacter michiganensis subsp. michiganensis & ICMP $2550^{\mathrm{T}}$ & Hungary & Lycopersicon esculentum \\
\hline Clavibacter michiganensis subsp. nebraskensis & ICMP $3298^{\mathrm{T}}$ & United States & Zea mays \\
\hline Clavibacter michiganensis subsp. tessellarius & ICMP $7221^{\mathrm{T}}$ & United States & Triticum aestivum \\
\hline Agromyces ramosus & ATCC $25173^{\mathrm{T}}$ & Unknown & Soil \\
\hline Agromyces cerinus subsp. cerinus & VKM Ac- $1340^{\mathrm{T}}$ & Russia & Soil \\
\hline Agromyces fucosus subsp. fucosus & VKM Ac- $1345^{\mathrm{T}}$ & Russia & Soil \\
\hline
\end{tabular}

${ }^{a}$ ATCC, American Type Culture Collection, Rockville, Md.; ICMP, International Collection of Microorganisms from Plants (formerly Plant Diseases Division Culture Collection), Auckland, New Zealand.

${ }^{b}$ Data from references 7,24 , and 54 .

c Recently described as Clavibacter toxicus (38).

taxonomic study of Clavibacter spp. strains possessing menaquinones of the MK-10 type and six "Corynebacterium sp." strains isolated from annual grasses. On the basis of the data obtained, a new genus, Rathayibacter, is proposed to accommodate Rathayibacter iranicus comb. nov., Rathayibacter rathayi comb. nov., Rathayibacter tritici comb. nov., and six Rathayibacter sp. strains.

\section{MATERIALS AND METHODS}

Bacterial strains. The strain designations and the relevant information concerning strain origins are shown in Table 1. All strains were maintained on modified Prauser medium 79 (35) (10 g of glucose, $5 \mathrm{~g}$ of peptone, $2 \mathrm{~g}$ of yeast extract, $2 \mathrm{~g}$ of Casamino Acids, $6 \mathrm{~g}$ of $\mathrm{NaCl}, 15 \mathrm{~g}$ of agar, 1 liter of distilled water [pH 7.4]).

Morphology. Morphological characteristics were studied by phase-contrast microscopy of 1-, 3-, and 7-day-old cultures grown on Prauser medium 79.

Physiology. Utilization of carbohydrates was tested by using modified ISP 9 medium (36) supplemented with $0.1 \%$ (wt/vol) yeast extract and $0.1 \%$ Casamino Acids. The different carbon sources were added at final concentrations of $1 \%$ (wt/vol). Basal medium with no added carbon source and basal medium supplemented with glucose were used for negative and positive controls, respectively. Modified Christensen medium (51) without glucose was used to assay the assimilation of organic acids at $\mathrm{pH} 6.8$; the different organic acids were added at final concentrations $0.5 \%$ (wt/vol). Production of acids from carbohydrates was assayed in a basal medium containing $0.1 \%$ (wt/vol) $\mathrm{NH}_{4} \mathrm{H}_{2} \mathrm{PO}_{4}, 0.02 \%$ $\mathrm{KCl}, 0.02 \% \mathrm{MgSO}_{4} \cdot 7 \mathrm{H}_{2} \mathrm{O}, 0.1 \%$ yeast extract, $0.1 \%$ Casamino Acids, $0.004 \%$ bromocresol purple, and $1.5 \%$ agar. A pronounced change of indicator color was defined as a positive reaction. Utilization of amino acids as sole sources of nitrogen was tested on a medium containing $1 \%$ glucose, $0.1 \% \mathrm{~K}_{2} \mathrm{HPO}_{4}, 0.05 \% \mathrm{MgSO}_{4} \cdot 7 \mathrm{H}_{2} \mathrm{O}, 0.05 \% \mathrm{NaCl}, 10 \mathrm{mg}$ of biotin per liter, $1 \mathrm{mg}$ of thiamine per liter, and 1.5\% agar. Growth on the basal medium supplemented with methionine was used as a positive control. Susceptibility to growth inhibitors and antibiotics was tested on NBY agar (47) modified as follows: the medium contained $0.8 \%$ nutrient broth (Difco), $0.2 \%$ Casamino Acids, $0.2 \%$ yeast extract, $0.5 \% \mathrm{NaCl}, 0.5 \%$ glucose, and $1.5 \%$ agar. Tests to determine degradation activities, reduction of nitrate, methyl red and Voges-Proskauer reactions, and hydrolysis of hippurate and other tests were performed by methods described previously $(17,19,20,26)$. All assays were done at $28^{\circ} \mathrm{C}$ unless indicated otherwise; cells grown on NBY agar at $28^{\circ} \mathrm{C}$ for 48 $h$ were used as inocula.

Bacteriocin production. The procedures of Gross and Vidaver (21) were used to test bacteriocin production on NBY agar and Prauser medium 79 agar.

Chemotaxonomy. Cell wall peptidoglycan preparations were obtained by using the methods of Schleifer and Kandler (42). The amino acid compositions of peptidoglycans were determined with a model LC 600 amino acid analyzer (Biotronic, Munich, Germany). Sugars in whole-cell hydrolysates $\left(1 \mathrm{M} \mathrm{HCl}, 105^{\circ} \mathrm{C}, 30 \mathrm{~min}\right)$ were analyzed by thin-layer chromatography (23). Cellular fatty acid methyl ethers were determined as described previously (17). Menaquinones were extracted and purified by the methods of Collins (6), and their compositions were assayed by using a model MAT 8430 mass spectrometer (Finnigan, Bremen, Germany). Phospholipids were isolated and analyzed by thin-layer chromatography as described previously (32).

Lysozyme-SDS test. Cell sensitivity to lysing agents (referred to as the lysozyme-sodium dodecyl sulfate [SDS] test) has been found to be useful in studies of plasmid profiles. 
The procedure described by Dobritsa (14), with slight modification (52), was used. Cultures were grown on modified Prauser medium 79 at $28^{\circ} \mathrm{C}$ for $44 \mathrm{~h}$. A $1-\mathrm{ml}$ portion of a culture suspension was harvested in a $1.5-\mathrm{ml}$ microcentrifuge tube by centrifugation, washed once with $300 \mu \mathrm{l}$ of a solution containing $10 \%$ sucrose in $0.05 \mathrm{M}$ Tris- $\mathrm{HCl}(\mathrm{pH}$ 8.0 ), and resuspended in $300 \mu$ lof the same solution supplemented with $15 \mu$ l of $0.5 \mathrm{M}$ disodium EDTA ( $\mathrm{pH} \mathrm{8.0)}$ and lysozyme (Sigma) $(100 \mathrm{mg} / \mathrm{ml}$ in TE buffer containing $0.05 \mathrm{M}$ Tris- $\mathrm{HCl}$ and $0.02 \mathrm{M}$ disodium EDTA [pH 8.0]) to a final concentration of $10 \mathrm{mg} / \mathrm{ml}$. The cells were allowed to lyse by incubating the suspension in a water bath at $37^{\circ} \mathrm{C}$ for $20 \mathrm{~min}$. Then, $350 \mu$ l of lysing solution (3.8\% SDS, $0.19 \mathrm{~N} \mathrm{NaOH}$, $0.05 \mathrm{M}$ Tris, $15 \%$ sucrose) was added. The lysates were heated at $60^{\circ} \mathrm{C}$ for $30 \mathrm{~min}$ in a water bath. Clearing of lysates was considered a positive reaction.

DNA base composition and DNA-DNA hybridization. DNA was prepared as described previously (17). The $\mathrm{G}+\mathrm{C}$ content of DNA was determined from its thermal denaturation midpoint (29) in $0.1 \times \mathrm{SSC}(1 \times \mathrm{SSC}$ is $0.15 \mathrm{M} \mathrm{NaCl}$ plus $0.015 \mathrm{M}$ sodium citrate) by using a Beckman model DU-8B spectrophotometer equipped with a thermoprogrammer. DNA base composition was calculated by using the equation of Owen and Pitcher (34). DNA from Micrococcus luteus VKM B-1314 ${ }^{\mathrm{T}}$ ( $\mathrm{T}=$ type strain), which contains $72 \mathrm{~mol} \%$ $\mathrm{G}+\mathrm{C}(29)$, was used as a reference. The extents of DNA reassociation between strains were determined by the method of Meyer and Schleifer (30) and Stackebrandt et al. (45), modified as described previously (17).

\section{RESULTS AND DISCUSSION}

All Clavibacter iranicus, Clavibacter rathayi, and Clavibacter tritici strains and six "Corynebacterium sp." strains isolated from Lolium rigidum, Avena fatua, Phalaris minor, and Phalaris paradoxa (Table 1) were similar in their basic chemotaxonomic features, including uncommon amino acid composition of purified peptidoglycans (alanine, glycine, glutamic acid, and $\mathrm{DAB}$ in a molar ratio of $1: 1: 1: 2$ ), basic phospholipids (phosphatidylglycerol and diphosphatidylglycerol), predominant unsaturated menaquinones with 10 isoprene units (MK-10), and major amounts of iso and anteiso methyl branched-chain fatty acids (Table 2). These characteristics were similar for the type strains of Clavibacter iranicus, Clavibacter rathayi, and Clavibacter tritici (2, $5,7,11,18,31,42)$, and these strains differed from strains of Clavibacter michiganensis (Clavibacter michiganensis subsp. michiganensis, Clavibacter michiganensis subsp. insidiosus, Clavibacter michiganensis subsp. nebraskensis, Clavibacter michiganensis subsp. tesselarius, and Clavibacter michiganensis subsp. sepedonicus) primarily in the type of menaquinones (MK-10 and MK-9, respectively).

The Clavibacter iranicus, Clavibacter rathayi, and Clavibacter tritici strains and six "Corynebacterium sp." strains also differed from the Clavibacter michiganensis subspecies strains in the following characteristics: lysozyme-SDS test (which probably indicates differences in cell wall composition); ability to utilize inositol, melibiose, L-rhamnose, and tagatose (Table 3); ability to produce bacteriocins; and resistance to bacteriocins of some Clavibacter spp. (52). In contrast to Clavibacter michiganensis strains, most of the strains with menaquinones of the MK-10 type contain xylose but not fucose in their cell walls (Tables 2 and 3 ).

According to the results of a numerical analysis of 85 strains of Clavibacter spp. and related species in which 126
TABLE 2. Differentiating characteristics of Rathayibacter species $^{a}$

\begin{tabular}{ccccc}
\hline Characteristic & $\begin{array}{c}\text { R. rathayi } \\
(n=5)^{b}\end{array}$ & $\begin{array}{c}\text { R. tritici } \\
(n=6)\end{array}$ & $\begin{array}{c}\text { iranicus } \\
(n=1)\end{array}$ & $\begin{array}{c}\text { Rathayi- } \\
\text { bacter sp } \\
(n=6)\end{array}$ \\
\hline
\end{tabular}

Cell wall sugars

Galactose

Xylose

Fatty acid composition

$$
(\%)
$$

iso- $15: 0$

anteiso-15:0

iso- $16: 0$

16:0

$(+)^{c}$
+

$(+)$

$+$

$\begin{array}{ll}+ & - \\ - & -\end{array}$

iso- $17: 0$

anteiso-17:0

17:0

Utilization of:

Xylose

L-Arabinose

Lactose

Mannitol

Sorbitol

Inulin

Citrate

Tartrate

Sebacinate

Acid production from:

Glucose

Galactose

Fructose

Mannose

Maltose

Xylose

Sucrose

Amino acid utilization

DL-Valine

Glutamic acid

DL-Ornithine

Hydrolysis of

Tween 21,

Tween 40 ,

and Tween 85

Tolerance to:

$5 \% \mathrm{NaCl}$

$0.030 \%$

potassium

tellurite

Voges-

Proskauer test

Methyl red test

Susceptibility to iranicin $^{d}$

$\begin{array}{ccrc}1.8-4.7 & 0.0-4.3 & 0.9 & 0.0-2.3 \\ 39.2-73.5 & 28.7-45.6 & 42.1 & 32.7-46.8 \\ 7.6-15.7 & 15.5-36.1 & 21.1 & 10.2-20.4 \\ 0.0-2.7 & 3.0-5.2 & 3.3 & 0.9-1.8 \\ 0.0-3.5 & 0.0-0.0 & 1.1 & 0.4-1.7 \\ 10.0-33.8 & 18.4-38.0 & 28.0 & 39.8-46.7 \\ 0.0-0.07 & 0.0-2.5 & 0.4 & 0.9-3.3\end{array}$

$\begin{array}{cccc}+ & + & + & - \\ + & + & + & - \\ + & + & + & - \\ + & + & + & - \\ (+) & + & + & - \\ - & + & - & - \\ + & + & + & - \\ + & + & + & - \\ (+) & + & - & -\end{array}$

${ }^{a}$ See Table 1 for information on the strains used. In addition, $R$. rathayi contained 37- and 83-kb plasmids and $R$. tritici contained a $50-\mathrm{kb}$ plasmid. We found no plasmids in $R$. iranicus or the Rathayibacter sp. strains.

${ }^{b} n$ is the number of strains tested.

${ }^{c}+$, positive reaction; - , negative reaction; $(+)$, reaction variable among strains.

${ }^{d}$ Iranicin is the bacteriocin of $R$. iranicus (21).

unit characters were used (53), all strains containing type MK-10 menaquinones as the predominant menaquinones (Clavibacter iranicus, Clavibacter rathayi, and Clavibacter tritici strains and six strains isolated from annual grasses) form a clear cluster distinct from the cluster of Clavibacter 
TABLE 3. Some diagnostic and differentiating characteristics of the genera Clavibacter, Rathayibacter, and Agromyces

\begin{tabular}{|c|c|c|c|}
\hline Characteristic & Clavibacter & Rathayibacter & Agromyces \\
\hline $\begin{array}{l}\text { Peptidoglycan } \\
\text { based on DAB } \\
\text { (type B2 } 2 \text { ) }\end{array}$ & $t^{b}$ & + & + \\
\hline Major menaquinone & MK-9 & MK-10 & MK-12 \\
\hline \multicolumn{4}{|l|}{ Cell wall sugars } \\
\hline Glucose & + & + & $(+)$ \\
\hline Galactose & + & $(+)$ & + \\
\hline Mannose & + & + & $(+)$ \\
\hline Rhamnose & + & + & + \\
\hline Xylose & - & $(+)$ & $(t)$ \\
\hline Fucose & $(+)$ & - & $(+)$ \\
\hline Tyvelose & - & - & $(+)$ \\
\hline Mycelium & - & - & + \\
\hline \multicolumn{4}{|l|}{ Utilization of: } \\
\hline Inositol & + & - & $(+)$ \\
\hline Melibiose & $(+)$ & - & $(+)$ \\
\hline L-Rhamnose & $(+)$ & - & + \\
\hline Tagatose & $(+)$ & - & - \\
\hline $\begin{array}{l}\text { Susceptibility to } \\
\text { iranicin }^{c}\end{array}$ & + & $(+)$ & - \\
\hline Lysozyme-SDS test & + & - & + \\
\hline $\begin{array}{l}\text { Usual sources of } \\
\text { isolation }\end{array}$ & $\begin{array}{l}\text { Plants or plant } \\
\text { substrates }\end{array}$ & Plants & Soil \\
\hline
\end{tabular}

\footnotetext{
${ }^{a}$ Data from reference 54.

$b+$, positive reaction; - , negative reaction; $(+)$, reaction variable among strains.

${ }^{c}$ Iranicin is the bacteriocin of $R$. iranicus (21).
}

michiganensis subspecies at a level of $71 \%$ (simple matching coefficient).

The heterogeneity of the original genus Clavibacter is also supported by our DNA-DNA hybridization data (Table 4). DNA relatedness values of 56 and $60 \%$ were observed between Clavibacter michiganensis subsp. michiganensis ICMP $2550^{\mathrm{T}}$ and two other strains with type MK-9 menaquinones (Clavibacter michiganensis subsp. nebraskensis ICMP $3298^{\mathrm{T}}$ and Clavibacter michiganensis subsp. tessellarius ICMP $7221^{\mathrm{T}}$ ). Clavibacter iranicus ICMP $3496^{\mathrm{T}}$ and Clavibacter tritici ICMP $2626^{\mathrm{T}}$ gave DNA relatedness values

TABLE 4. Levels of DNA relatedness among Clavibacter, Rathayibacter, and Agromyces strains

\begin{tabular}{|c|c|c|c|}
\hline \multirow[b]{2}{*}{ Strain } & \multicolumn{3}{|c|}{$\begin{array}{l}\% \text { Relatedness to }\left[\mathrm{H}^{3}\right] \mathrm{DNA} \\
\text { from: }\end{array}$} \\
\hline & $\begin{array}{l}\text { Strain } \\
\text { ICMP } \\
2550^{\mathrm{T}}\end{array}$ & $\begin{array}{l}\text { Strain } \\
\text { ICMP } \\
2574^{T}\end{array}$ & $\begin{array}{c}\text { Strain } \\
\text { VKM } \\
\text { Ac-1340 }\end{array}$ \\
\hline $\begin{array}{l}\text { Clavibacter michiganensis subsp. } \\
\text { michiganensis ICMP } 2550^{\mathrm{T}}\end{array}$ & 100 & 7 & 10 \\
\hline $\begin{array}{l}\text { Clavibacter michiganensis subsp. } \\
\text { nebraskensis ICMP } 3298^{\mathrm{T}}\end{array}$ & 60 & & \\
\hline $\begin{array}{l}\text { Clavibacter michiganensis subsp. } \\
\text { tessellarius ICMP } 7221^{\mathrm{T}}\end{array}$ & 56 & & \\
\hline$R$. rathayi ICMP $2574^{\mathrm{T}}$ & 9 & 100 & 12 \\
\hline R. tritici ICMP $2626^{\mathrm{T}}$ & 8 & 43 & \\
\hline R. iranicus ICMP $3496^{\mathrm{T}}$ & 8 & 16 & \\
\hline $\begin{array}{l}\text { Agromyces ramosus ATCC } \\
\qquad 5173^{\mathrm{T}}\end{array}$ & 7 & 5 & 12 \\
\hline $\begin{array}{l}\text { Agromyces cerinus subsp. } \\
\text { cerinus VKM Ac- } 1340^{T}\end{array}$ & 10 & 7 & 100 \\
\hline $\begin{array}{l}\text { Agromyces fucosus subsp. } \\
\text { fucosus VKM Ac- } 1345^{\mathrm{T}}\end{array}$ & & & 40 \\
\hline
\end{tabular}

of 16 and $43 \%$ with Clavibacter rathayi ICMP $2574^{\mathrm{T}}$, whereas the levels of DNA relatedness between the type strain of Clavibacter michiganensis subsp. michiganensis and the type strains of Clavibacter iranicus, Clavibacter rathayi, and Clavibacter tritici were 7 to $9 \%$. The levels of DNA relatedness between representatives of the genera Clavibacter and Agromyces have been found to be in approximately the same range (5 to 10\%) (54). These data indicate that the strains of Clavibacter spp. which we studied can be separated on the basis of DNA relatedness values into two distinct groups rather than at the species level.

Also, in an independent study, Riley et al. (39) showed that strains of Clavibacter spp. may be divided into at least two groups, one centered around Clavibacter michiganensis and its subspecies and the other accommodating Clavibacter rathayi, Clavibacter tritici, and Clavibacter iranicus, on the basis of their allelic profiles, which reflect possible genetic relationships among organisms.

The results of immunodiffusion and enzyme-linked immunosorbent assays are difficult to interpret taxonomically as a rule (8). Nevertheless, serological data of this kind indicate that Clavibacter rathayi, Clavibacter tritici, and Clavibacter iranicus are serologically distinct from the other plantpathogenic corynebacteria, including Clavibacter michiganensis $(27,37)$.

Moreover, in contrast to Clavibacter michiganensis and Clavibacter xyli, Clavibacter tritici, Clavibacter iranicus, "Corynebacterium sp." strains isolated from $L$. rigidum, and probably Clavibacter rathayi are associated with nematodes belonging to the genus Anguina, require these animals as vectors $(1,8,20,38)$, and exhibit specific adhesion to Anguina species (1). In addition, Clavibacter rathayi, Clavibacter tritici, Clavibacter iranicus, and "Corynebacterium sp." strains were isolated only from cereal plants (Table 1) $(7,24,40,48)$.

Thus, the phenotypic and genetic differences, as well as the peculiarities of ecology, of these Clavibacter spp. suggest that the coryneform bacteria with type B2y peptidoglycan can be separated into two taxa which can be considered separate genera. On the basis of the considerations discussed above, we propose that a new genus, Rathayibacter, should be established for three species of phytopathogenic bacteria previously placed in the genus Clavibacter (Rathayibacter rathayi comb. nov., Rathayibacter tritici comb. nov. and Rathayibacter iranicus comb. nov.), as well as for Rathayibacter sp. strains isolated from $A$. fatua, L. rigidum, $P$. minor, and $P$. paradoxa (these strains may be responsible for annual ryegrass toxicity and may be members of the recently described taxon Clavibacter toxicus sp. nov. [38]).

The type strains of the species are $R$. rathayi VKM Ac-1601 (= ICMP 2574), $R$. iranicus VKM Ac-1602 (= ICMP 3496), and $R$. tritici VKM Ac-1603 (= ICMP 2626).

The strains of Rathayibacter species were differentiated from each other (Table 2) by the following characteristics: presence of xylose and galactose in the cell walls, fatty acid composition, ability to assimilate various sources of carbon and nitrogen, hydrolytic activity, tolerance to $5 \% \mathrm{NaCl}$ and $0.03 \%$ potassium tellurite, susceptibility to iranicin, absence or presence of plasmids of certain sizes (52), and specificity for several hosts (Table 1).

The strains referred to above as Rathayibacter sp. strains are similar to $R$. iranicus in cell wall sugar composition (glucose, mannose, and rhamnose) (Table 2) but are clearly differentiated from $R$. iranicus, $R$. rathayi, and $R$. tritici by their morphology (shorter rods [ 0.4 to 0.6 by 0.5 to $1.6 \mu \mathrm{m}]$ ), nutrient requirements, time needed to reach the stationary 
growth phase (4 and 2 days, respectively), physiological properties, absence of plasmids (52), host specificity (Table $1)$, and the predominant symptoms of diseases $(8,38,40,48)$. A phenotypic similarity analysis (53) showed that $R$. rathayi, $R$. tritici, $R$. iranicus, and the Rathayibacter $\mathrm{sp}$. strains isolated from annual grasses form four phena at approximately the same level inside the Rathayibacter cluster. Taken collectively, these properties leave no doubt that the Rathayibacter sp. strains are members of a separate species.

The data described above indicate the need to formally name the Rathayibacter sp. strains isolated from annual grasses. In this paper we do not present a formal proposal because these strains probably are members of the species recently described by Riley and Ophel (38) as Clavibacter toxicus, at least judging by the biochemical and physiological criteria used in our work. In addition, some Rathayibacter sp. strains were isolated from $L$. rigidum, the same source as all of the Clavibacter toxicus strains (38). In fact, one of the strains (strain ICMP 6307) classified as belonging to Clavibacter toxicus (38) was included in our study and was recovered in a close cluster (simple matching coefficient, 95\%), to which the name Rathayibacter sp. was applied. However, we have not had the opportunity to perform side-by-side experimental comparisons with the type strain of Clavibacter toxicus (strain ICMP 9525). Perhaps after such a study (by us or other workers) Clavibacter toxicus may be transferred to the genus Rathayibacter as Rathayibacter toxicus comb. nov. For differentiating purposes both the criteria described in our study and those used by Riley and Ophel (38) can be employed.

We feel that our proposal to reclassify some members of the genus Clavibacter and establish the new genus Rathayibacter for a group of coryneform bacteria with an extensive record of taxonomic and ecological studies might not meet with widespread approval, at least initially. On the other hand, we visualize our effort as a modest step on the important road toward reconciliation of approaches, as broadly outlined previously $(33,50)$. Our results and suggestions do not seem to contradict the interests of either a coherent taxonomic picture or a practically manageable identification scheme for a group of bacteria with type B2 $\gamma$ peptidoglycan in their cell walls.

Future studies on the taxonomic structure of bacteria which contain $\mathrm{DAB}$ in their cell walls not only might benefit from the data accumulating for representatives of the three genera mentioned above (Clavibacter, Rathayibacter, and Agromyces), but also might take into account information reported previously $(7,11,18,31,39,48)$ for such bacteria as "Conynebacterium aquaticum," "Corynebacterium mediolanum," "Flavobacterium dehydrogenans," "Corynebacterium agropyri," "Corynebacterium okanaganae," "Brevibacterium helvolum," and "Corynebacterium bovis" ATCC 13722.

Description of Rathayibacter gen. nov. Rathayibacter (Ra. thay'. i. bac. ter. M.L. gen. n. rathayi, of Rathay, referring to E. Rathay, the Australian plant pathologist who first isolated members of the genus; L. masc. n. bacter, rod; N. L. n. Rathayibacter, rod isolated by Rathay). Irregular, pleomorphic, short rods (width, 0.4 to $0.8 \mu \mathrm{m}$; length, 0.5 to $1.8 \mu \mathrm{m})$. V-forms and sometimes short cell chains are formed; a clear rod-coccus cycle is not observed. Nonmotile. Nonsporulating. Gram positive and not acid fast. Obligately aerobic. Chemoorganotrophic, having an oxidative type of catabolism. Catalase positive. Nutritionally exacting. Mesophilic; optimal growth occurs at temperatures between 24 and $28^{\circ} \mathrm{C}$.
Cell wall peptidoglycan contains alanine, glutamic acid, glycine, and DAB (1:1:1:2). Cell wall sugars include glucose, mannose, and rhamnose. Xylose and galactose also occur in the cell walls of some strains. Menaquinones are of the MK-10 type. Mycolic acids are absent. Among the fatty acids, branching saturated fatty acids of the anteiso type (anteiso-15:0 and anteiso-17:0) predominate. Diagnostic phospholipids are represented by phosphatidylglycerol, diphosphatidylglycerol, and unknown glycosyldiacylglycerols; several strains contain lyso-phosphatidylglycerol. The $\mathrm{G}+\mathrm{C}$ contents of DNAs range from 63 to $72 \mathrm{~mol} \%$.

Most strains utilize cellobiose, fructose, galactose, glucose, glycerol, maltose, mannose, melezitose, methyl- $\alpha-D-$ arabinopyranoside, raffinose, salicin, sucrose, and trehalose as sole carbon sources but do not utilize adonitol, dextrin, dulcitol, erythritol, inositol, lyxose, mannitol, melibiose, L-rhamnose, tagatose, or sorbitol. No acids are formed from dulcitol, inositol, lactose, mannitol, melibiose, L-rhamnose, or sorbitol. Acid production from other sugars is variable.

Acetate, formate, fumarate, gluconate, glutarate, $\alpha$-ketoglutarate, lactate, malate, propionate, succinate, and valerate are utilized. Phenylalanine and methionine are assimilated, but most amino acids are not used as sole sources of nitrogen.

Casein, elastin, guanine, hypoxanthine, testosterone, Tween 60 , Tween 65 , Tween 80 , starch, urea, and xanthine are not hydrolyzed or decomposed. Nitrate is not reduced to nitrite. Hydrolysis of hippurate is negative. Methyl red reduction and Voges-Proskauer tests are variable. Growth occurs at temperatures between 16 and $35^{\circ} \mathrm{C}$, but not at 10 or $37^{\circ} \mathrm{C}$. Susceptible to $7 \% \mathrm{NaCl}$ and $0.02 \%$ potassium tellurite but tolerates $0.01 \%$ potassium tellurite.

Some strains produce bacteriocins. Most strains contain plasmids.

Isolated mainly from cereal crops and annual cereal grasses. The type species of the genus is Rathayibacter rathayi.

Characteristics of the Rathayibacter sp. strains. The Rathayibacter sp. strains isolated from annual grasses (see above) had the characteristics described below. Irregular, pleomorphic, short rods (width, 0.4 to $0.6 \mu \mathrm{m}$; length, 0.5 to $1.6 \mu \mathrm{m})$. V-forms and sometimes short cell chains are formed; a clear rod-coccus cycle is not observed. Nonmotile. Nonsporulating. Gram positive and not acid fast. Obligately aerobic. Chemoorganotrophic, having an oxidative type of catabolism. Catalase positive. Nutritionally exacting. Mesophilic; optimal growth occurs at temperatures between 24 and $28^{\circ} \mathrm{C}$.

Cell wall sugars include glucose, mannose, and rhamnose. Most strains utilize cellobiose, fructose, galactose, glucose, glycerol, maltose, mannose, melezitose, methyl-arabinopyranoside, raffinose, salicin, sucrose, and trehalose as sole carbon sources but do not use adonitol, L-arabinose, dextrin, dulcitol, erythritol, inositol, lactose, D-xylose, mannitol, melibiose, L-rhamnose, tagatose, and sorbitol. Acid is produced from galactose. No acids are formed from dulcitol, fructose, glucose, inositol, lactose, maltose, mannitol, melibiose, L-rhamnose, sorbitol, sucrose, and D-xylose. Acetate, formate, fumarate, gluconate, glutarate, $\alpha$-ketoglutarate, lactate, malate, propionate, succinate, and valerate are utilized. An alkaline reaction is not observed with citrate, malonate, sebacinate, or tartrate. Phenylalanine, glutamic acid, ornithine, and methionine are assimilated, but most amino acids are not used as sole nitrogen sources.

Casein, elastin, guanine, hypoxanthine, testosterone, Tween 21, Tween 40, Tween 60, Tween 80, Tween 85, 
starch, urea, and xanthine are not hydrolyzed or decomposed. Nitrate is not reduced to nitrite. Hydrolysis of hippurate is negative. Methyl red reduction and VogesProskauer tests are negative. Growth occurs at temperatures between 20 and $35^{\circ} \mathrm{C}$ but not at 14 or $37^{\circ} \mathrm{C}$. Susceptible to $5 \%$ $\mathrm{NaCl}$ and $0.02 \%$ potassium tellurite but tolerates $0.01 \%$ potassium tellurite.

Susceptible to bacteriocin produced by $R$. iranicus ICMP $3496^{\mathrm{T}}$. Plasmids are not observed. The $\mathrm{G}+\mathrm{C}$ content of the DNA is $63 \mathrm{~mol} \%$.

Isolated mainly from annual cereal grasses.

\section{ACKNOWLEDGMENTS}

We thank H. J. Phaff and reviewers of the manuscript for constructive criticism and expert help with the language. Special thanks are due to J. M. Young (Curator, International Collection of Microorganisms from Plants) for providing of strains and editorial comments, as well as sharing some ideas.

\section{REFERENCES}

1. Bird, A. F. 1981. The Anguina-Coryneform association, p. 303-323. In B. M. Zuckerman and R. A. Rhode (ed.), Plant parasitic nematodes, vol. 3. Academic Press, New York.

2. Bousfield, I. J., G. L. Smith, T. R. Dandod, and G. Hobbs. 1983. Numerical analysis of total fatty acid profiles in the identification of coryneform, nocardioform and some other bacteria. J. Gen. Microbiol. 129:375-394.

3. Carlson, R. R., and A. K. Vidaver. 1982. Taxonomy of Corynebacterium plant pathogens, including a new pathogen of wheat, based on polyacrylamide gel electrophoresis of cellular proteins. Int. J. Syst. Bacteriol. 32:315-326.

4. Casida, L. E. 1986. Genus Agromyces, p. 1329-1331. In P. H. A. Sneath, N. S. Mair, M. E. Sharpe, and J. G. Holt (ed.), Bergey's manual of systematic bacteriology, vol. 2. The Williams \& Wilkins Co., Baltimore.

5. Collins, M. D. 1983. Cell wall peptidoglycan and lipid composition of the phytopathogen Corynebacterium rathayi (Smith). Syst. Appl. Microbiol. 4:193-195.

6. Collins, M. D. 1985 . Isoprenoid quinone analysis in bacterial classification and identification, p. 267-287. In M. Goodfellow and D. E. Minnikin (ed.), Chemical methods in bacterial systematics. Academic Press, Inc. (London), Ltd., London.

7. Collins, M. D., and J. F. Bradbury. 1986. Plant pathogenic species of Corynebacterium, p. 1276-1284. In P. H. A. Sneath, N. S. Mair, M. E. Sharpe, and J. G. Holt (ed.), Bergey's manual of systematic bacteriology, vol. 2. The Williams \& Wilkins Co., Baltimore.

8. Collins, M. D., and J. F. Bradbury. 1991. The genera Agromyces, Aureobacterium, Clavibacter, Curtobacterium, and Microbacterium, p. 1355-1368. In A. Balows, H. A. Trüper, M. Dworkin, W. Harder, and K.-H. Schleifer (ed.), The prokaryotes, vol. 2. Springer-Verlag, Inc., Berlin.

9. Collins, M. D., J. Brown, and D. Jones. 1988. Brachybacterium faecium gen nov., a coryneform bacterium from poultry deep litter. Int. J. Syst. Bacteriol. 38:45-48.

10. Collins, M. D., M. Dorsch, and E. Stackebrandt. 1989. Transfer of Pimelobacter tumescens to Terrabacter gen. nov. as Terrabacter tumescens comb. nov. and of Pimelobacter jensenii to Nocardioides as Nocardioides jensenii comb. nov. Int. J. Syst. Bacteriol. 39:1-6.

11. Collins, M. D., and D. Jones. 1980 . Lipids in the classification and identification of coryneform bacteria containing peptidoglycans based on 2,4-diaminobutyric acid. J. Appl. Bacteriol. 48:459-470.

12. Collins, M. D., D. Jones, R. M. Keddie, R. M. Kroppenstedt, and K. H. Schleifer. 1983. Classification of some coryneform bacteria in a new genus, Aureobacterium. Syst. Appl. Microbiol. 4:236-252.

13. Davis, M. I., A. G. Gillaspie, A. K. Vidaver, and R. W. Harris. 1984. Clavibacter: a new genus containing some phytopathogenic coryneform bacteria, including Clavibacter $x y l i$ subsp. $x y l i$ sp. nov., subsp. nov. and Clavibacter xyli subsp. cynodontis subsp. nov., pathogens that cause ratoon stunting disease of sugarcane and bermudagrass stunting disease. Int. J. Syst. Bacteriol. 34:107-117.

14. Dobrista, S. V. 1984. Large plasmids in an actinomycete. FEMS Microbiol. Lett. 23:35-39.

15. Dopfer, H., E. Stackebrandt, and F. Fiedler. 1982. Nucleic acid hybridization studies on Microbacterium, Curtobacterium, Agromyces and related taxa. J. Gen. Microbiol. 128:1697-1708.

16. Dye, D. W., and W. J. Kemp. 1977. A taxonomic study of plant pathogenic Corynebacterium species. N. Z. J. Agric. Res. 20:563-582.

17. Evtushenko, L. I., V. N. Akimov, S. V. Dobritsa, and S. D. Taptykova. 1989. A new species of actinomycete, Amycolata alni. Int. J. Syst. Bacteriol. 39:72-77.

18. Fiedler, F., and O. Kandler. 1973. Die Aminosäuresequenz von 2,4-Diaminobuttersäure enthalten Mureinen bei verschiedenen coryneformen Bakterien und Agromyces ramosus. Arch. Mikrobiol. 89:51-66.

19. Goodfellow, M. 1971. Numerical taxonomy of some nocardioform bacteria. J. Gen. Microbiol. 69:33-80.

20. Gordon, R. E., D. A. Barnett, J. E. Handerhan, and C. H.-N. Pang. 1974. Nocardia coeliaca, Nocardia autotrophica and the nocardin strain. Int. J. Syst. Bacteriol. 24:54-63.

21. Gross, D. C., and A. K. Vidaver. 1979. Bacteriocins of phytopathogenic Corynebacterium species. Can. J. Microbiol. 25: 367-374.

22. Gupta, P., and G. Swarup. 1972. Ear-cockle and yellow ear rot disease of wheat. II. Nematode bacterial association. Nematologia 18:320-324.

23. Hasegawa, T., M. Takizawa, and S. Tanida. 1983. A rapid analysis for chemical grouping of aerobic actinomycetes. J. Gen. Appl. Microbiol. 29:319-322.

24. International Collection of Microorganisms from Plants. 1988. Catalogue, p. 5-9. Plant Diseases Division, Department of Scientific and Industrial Research, Auckland, New Zealand.

25. Jensen, H. J. 1934. Studies on saprophytic mycobacteria and corynebacteria. Proc. Linn. Soc. N.S.W. 59:19-61.

26. Kovacs, N. 1956. Identification of Pseudomonas pyocyanea by the oxidase reaction. Nature (London) 178:703-705.

27. Lazar, I. 1968. Serological relationships of corynebacteria. J. Gen. Microbiol. 52:77-88.

28. Lehmann, K. B., and R. Neumann. 1896. Atlas und Grundriss der Bacteriologie und Lehrbuch der speciellen bacteriologischen Diagnostik, 1st ed. J. F. Lehmann, Munich.

29. Marmur, J., and P. Doty. 1962. Determination of the base composition of deoxyribonucleic acid from its thermal denaturation temperature. J. Mol. Biol. 5:109-118.

30. Meyer, S. A., and K. H. Schleifer. 1978. Deoxyribonucleic acid reassociation in the classification of coagulase-positive staphylococci. Arch. Microbiol. 117:183-188.

31. Minnikin, D. E., M. Goodfellow, and M. D. Collins. 1978. Lipid composition in the classification and identification of coryneform and related taxa, p. 85-160. In I. J. Bousfield and A. G. Callely (ed.), Coryneform bacteria. Academic Press, London.

32. Minnikin, D. E., A. G. O'Donnel, M. Goodfellow, G. Alderson, M. Athalye, A. Schaal, and J. H. Parlett. 1984. An integrated procedure for the extraction of bacterial isoprenoid quinones and polar lipids. J. Microb. Methods 2:233-241.

33. Murray, R. G. E., D. J. Brenner, R. R. Colwell, P. De Vos, M. Goodfellow, P. A. D. Grimont, N. Pfennig, E. Stackebrandt, and G. A. Zavarzin. 1990. Report of the Ad Hoc Committee on Approaches to Taxonomy within the Proteobacteria. Int. J. Syst. Bacteriol. 40:213-215.

34. Owen, R. J., and D. Pitcher. 1985. Current methods for estimating DNA base composition and levels of DNA-DNA hybridization, p. 67-93. In M. Goodfellow and D. E. Minnikin (ed.), Chemical methods in bacterial systematics. Academic Press, Inc. (London), Ltd., London.

35. Prauser, H. 1976. Nocardioides, a new genus of the order Actinomycetales. Int. J. Syst. Bacteriol. 26:58-65.

36. Pridham, T. G., and D. Gottlieb. 1948. The utilization of carbon compounds by some Actinomycetales as an aid for species 
determination. J. Bacteriol. 56:107-114.

37. Riley, I. T. 1987. Serological relationships between strains of coryneform bacteria responsible for annual ryegrass toxicity and other plant-pathogenic corynebacteria. Int. J. Syst. Bacteriol. 35:153-159.

38. Riley, I. T., and K. M. Ophel. 1992. Clavibacter toxicus sp. nov., the bacterium responsible for annual ryegrass toxicity in Australia. Int. J. Syst. Bacteriol. 42:64-68.

39. Riley, I. T., T. B. Reardon, and A. C. McKay. 1988. Genetic analysis of plant pathogenic bacteria in the genus Clavibacter using allozyme electrophoresis. J. Gen. Microbiol. 134:30253030 .

40. Sabet, A. K. 1954. On the host range and systematic position of the bacteria responsible for the yellow slime diseases of wheat (Triticum vulgare Vill.) and cocksfoot grass (Dactylis glomerata L.). Ann. Appl. Biol. 41:606-611.

41. Scharif, G. 1961. Corynebacterium iranicum sp. nov. on wheat (Triticum vulgare $\mathbf{L}$.) in Iran, and a comparative study of it with C. tritici and C. rathayi. Entomol. Phytopathol. Appl. 19:1-24.

42. Schleifer, K. H., and O. Kandler. 1972. Peptidoglycan types of bacterial cell walls and their taxonomic implications. Bacteriol. Rev. 36:407-477.

43. Skerman, V. B. D., V. McGowan, and P. H. A. Sneath (ed.). 1980. Approved lists of bacterial names. Int. J. Syst. Bacteriol. 30:225-420.

44. Stackebrandt, E., J. Smida, and M. D. Collins. 1988. Evidence of phylogenetic heterogeneity within the genus Rhodococcus: revival of the genus Gordona (Tsukamura). J. Gen. Appl. Microbiol. 34:341-348.

45. Stackebrandt, E., B. Wunner-Füssl, V. J. Fowler, and K. H. Schleifer. 1981. Deoxyribonucleic acid homologies and ribosomal ribonucleic acid similarities among spore-forming members of the order Actinomycetales. Int. J. Syst. Bacteriol. 31:420 431.

46. Starr, M. P., M. Mandel, and N. Murata. 1975. The phytopatho- genic coryneform bacteria in the light of DNA base composition and DNA-DNA segmental homology. J. Gen. Appl. Microbiol. 21:13-26.

47. Vidaver, A. K. 1967. Synthetic and complex media for rapid detection of fluorescence of phytopathogenic pseudomonads: effect of the carbon source. Appl. Microbiol. 15:1523-1524.

48. Vidaver, A. K. 1982 . The plant pathogenic corynebacteria. Annu. Rev. Microbiol. 36:495-517.

49. Vidaver, A. K., and M. Mandel. 1974. Corynebacterium nebraskense, a new, orange-pigmented phytopathogenic species. Int. J. Syst. Bacteriol. 24:482-485.

50. Wayne, L. G., D. J. Brenner, R. R. Colwell, P. A. D. Grimont, O. Kandler, M. I. Krichevsky, L. H. Moore, W. E. C. Moore, R. G. E. Murray, E. Stackebrandt, M. P. Starr, and H. G. Trüper. 1987. Report of the Ad Hoc Committee on Reconciliation of Approaches to Bacterial Systematics. Int. J. Syst. Bacteriol. 37:463-464.

51. Yamada, K., and K. Komagata. 1972. Taxonomic studies on coryneform bacteria. IV. Morphological, cultural, biochemical, and physiological characteristics. J. Gen. Appl. Microbiol. 18:399-416.

52. Zgurskaya, H. I., S. V. Dobritsa, L. I. Evtushenko, and L. V. Kalakoutskii. Unpublished data.

53. Zgurskaya, H. I., L. I. Evtushenko, V. N. Akimov, T. G. Dobrovolskaya, and L. V. Kalakoutskii. Submitted for publication.

54. Zgurskaya, H. I., L. I. Evtushenko, V. N. Akimov, H. V. Voyevoda, T. G. Dobrovolskaya, L. V. Lysak, and L. V. Kalakoutskii. 1992. Emended description of the genus Agromyces and description of the new species and subspecies Agromyces cerinus subsp. cerinus sp. nov., subsp. nov., Agromyces cerinus subsp. nitratus sp. nov., subsp. nov., Agromyces fucosus subsp. fucosus sp. nov., subsp. nov., and Agromyces fucosus subsp. hippuratus sp. nov., subsp. nov. Int. J. Syst. Bacteriol. 42:635-641. 